\title{
The importance of the photographic collection conservation for the Geography: understanding the present looking at the past
}

\author{
La importancia de la conservación de los acervos \\ fotográficos para la Geografía: entender el presente \\ mirando el pasado
}

\author{
Régia Estevam Alves* \\ Maria José Roxo**
}

Fecha de recibido: 17 de abril de 2019

Fecha de aceptado: 30 de octubre de 2019

\begin{abstract}
This study has for objective to detach the importance of the use of pictures in geographical studies and the preservation of collections of old images. Presenting, as example, an analysis of the agricultural expansion in the municipal districts of Jataí and Serranópolis, in the state of Goiás, Brazil. For that data of planted area and agricultural production were picked up in the two municipal districts; research accomplishment to field in the historical museums of those municipal districts for gathering pictures and news in newspapers and old magazines. Thereupon it was made an analysis of the agricultural data correlated with the images in news of newspapers and old magazines. The results showed as the pictures, whether individual or in news sections, they can help to understand the processes of changes in agricultural activities. Beyond showing the importance of the conservation and the use of pictures for geographical studies.

Key words: old images, geographical studies, past and present.

* University of Social Sciences and Human of the New University of Lisbon.

E-mail: regiaestevam@gmail.com.

* Department of Geography/University of Social Sciences and Human of the New University of Lisbon.
\end{abstract}




\section{Resumen}

Este estudio tiene por objetivo destacar la importancia del uso de fotografías en estudios geográficos y la preservación de acervos de imágenes antiguas. Presentando, como ejemplo, un análisis de la expansión agrícola en los municipios de Jataí y Serranópolis, en el estado de Goiás, Brasil. Para ello se recogieron datos de área plantada y producción agrícola en los municipios; realización de investigación de campo en los museos históricos de esos municipios para la recolección de fotografías y noticias en periódicos y revistas antiguas. Posteriormente se hizo un análisis de los datos agrícolas correlacionados con las imágenes en noticias de periódicos y revistas antiguas. Los resultados mostraron cómo las fotografías, tanto individuales o en noticieros, pueden ayudar a entender los procesos de cambio en las actividades agrícolas. Además, muestra la importancia de la conservación de este material para estudios geográficos.

Palabras clave: imágenes antiguas, estudios geográficos, pasado y presente.

\section{Introduction}

One of the crucial methods in Geography is the observation, the description, and analyses of documents or the use of representative images whether they are drawings descriptive in locus, outlines, maps, pictures or satellite images for the explanation of facts and phenomena of the social and natural way. However, the use of images, be her of any type is important in the studies of facts and phenomenon of the present time, but it becomes still more important when the researcher crosses the old images with current images, together with data and information, to understand the historical process. It's the exercise of looking the past to understand the present from a given reality. The idea of this study emerged from the need of complementing data and information of the research for the thesis and herewith to understand the phenomenon and facts happened as much in the present as in the past.

Thus, it was decided to analyze the processes of changes in agricultural activities as the planted area and the production among the years of 1995 and 2014 in the municipal districts of Jataí and Serranópolis, in the state of Goiás, Brazil.

The agricultural data were obtained in the Brazilian Institute of Geography and Statistics (IBGE), which provided data and information in what refer to the types of cultivations, planted area and agricultural production. The images as old pictures were obtained starting from a field research in the historical museums of the municipal districts of Jataí and Serranópolis, in the state of Goiás, Brazil. Newspapers and magazines published among the years of 1975 and 2014 were 
analyzed, where it was possible to organize a database with 506 pictures and referring news to different facts or phenomenon tied to the Nature or socioeconomic information. In this context, this work presents an abbreviation reflection regarding the use of images in studies along the history of the Geography and what form it has contributed; analyses about the similarity among the old and actual images with the agricultural expansion in the municipal districts of Jataí and Serranópolis, in the state of Goiás, Brazil.

\section{The use of images along the history of the Geography}

Historically, the observation and description were, and it is still, one of the methods of geographical studies. Like this, the use of representative images of the study object has been used more and more, and gotten better. From the historical point of view, the description was the method used by the Greeks to trace features of the diversity of the Earth, but it lacked them more specific knowledge on relief, soils and vegetation (Claval, 2006). Then in the Medium Age, its representation was had under form of paintings from that the eyes got to visualize. Alexander Von Humbort, Paul Vidal of La Blache, Max Sorre, Jean Tricart, Elisée Reclus, among so many other, valued the description from what were observed to present places under landscape form.

In the early eighteenth century, the development of scientific thinking about the world was increasingly based on image analysis rather than on written texts due to the realization that in Western societies the advancement of technology has fostered multisensory knowledge. With the technological development, the forms of registrations of images have been more and more perfect, such as the picture.

Officially registered as invention of Louis Daguerre in 1939, photography is the first means of automatic image production. In a brief description, according to Monteiro (2006), photography is a clipping of the real, the freezing of a moment separated from the succession of events. Rios, Costa and Mendes (2016) state that photography represents a means of automatic production, which assumes the role of instrument of mediation, registration and filing. Photographic images are ambiguous and subject to multiple interpretations. Photographs are an important tool in qualitative research in various areas of science.

In the development of scientific research, photography serves not only as a source of data, but also as an object, instrument and research results. Traditionally photography is used to document events, phenomena and processes in the humanities. It is an iconic high quality resource that can activate people's memories or stimulate them to elaborate analyzes of complex situations and processes (Warren, 2009; Rios et al., 2016).

In this context, the epistemic value of photography as an image stands out due to the information that the photo brings about the world. Photographs can produce information and data that broaden our understanding of the object of 
study, as it records details that may prompt viewers to develop a more accurate reflection of what is being analyzed. In geography, photography is not a traditional source of data or information in research development. However, in recent years photography has been used as a complementary resource of information in geographic studies.

Now it is possible to obtain images of satellites of high resolution, as well as aerial or terrestrial pictures that help in the development of researches in different fields of performance of the Geography, as Humbert (1979) mentions. The author detaches the relevance of the aerial pictures and its applicability in studies related to urban, rural and industrial themes. Humbert (1979) elucidates that he dedicated a long time overflying and photographing different landscapes, the one that made possible organize him a photographic collection that is possible to review when its necessary. That allows an analysis with larger accuracy of the any other type of document regarding the study object, because it is what the eyes see in the picture. According to him, the photographic registration keeps a memory and from that we can accompany the processes of changes and the new arrangements.

Bass (2011) that monitored the transformation of Honduras vegetation from photographic records emphasizes the importance of using photography in scientific research. According to Bass (2011), photography can be used as a scientific method, based on photographic repetition, offering the possibility of a more detailed observation of the transformations of the object of study.

Another example is the study by Abrantes (2013) on photographic archives obtained from geographical excursions. According to Abrantes (2013), photographs are still seen as special documents, both in the archival area, which separates from the rest of the collection for the purpose of scientific technical treatment, as well as in the area of historical studies, which serves as a source or object of research. Photographs help to reconstruct, analyze and understand an entire context. The use of statistical surveys in geographic studies, known as quantitative geography, and the introduction of new technologies such as aerial photography and satellite imagery contributed to the Brazilian Institute of Geography and Statistics in 1968 to stop promoting field trips.

In Brazil, the photography is very used as didactic resource in Geography's teaching in the schools. According to Silva and Ramirez (2014) and Izidoro and Correia (2017) they are unanimous in affirming that the photography is a mean of reading the geographical space just not limiting its illustrative and little reflexive function. Starting from the use of pictures it is possible to produce collective dialogues with speeches based on geographical knowledge in the schools.

Therefore, the preservation of the individual pictures is important, however, more important it is still the preservation of documents as newspapers and magazines where the publication of pictures is accompanied of information in form of news, that it can help in the understanding of a certain fact, event or natural phenomenon. To proceed it is presented in the quality of example, how 
the use of old and actual pictures can help to understand the process of agricultural expansion, its relation with the data of planted area and production in the municipal districts of Jataí and Serranópolis, in the state of Goiás, Brazil.

\section{The analogy among old and actual images with the agricultural expansion}

\section{Location and characterization of the study area}

In location terms and general characterization, the municipal districts of Jatai and Serranópolis belong to the state of Goiás in Brazil (Figure 1).
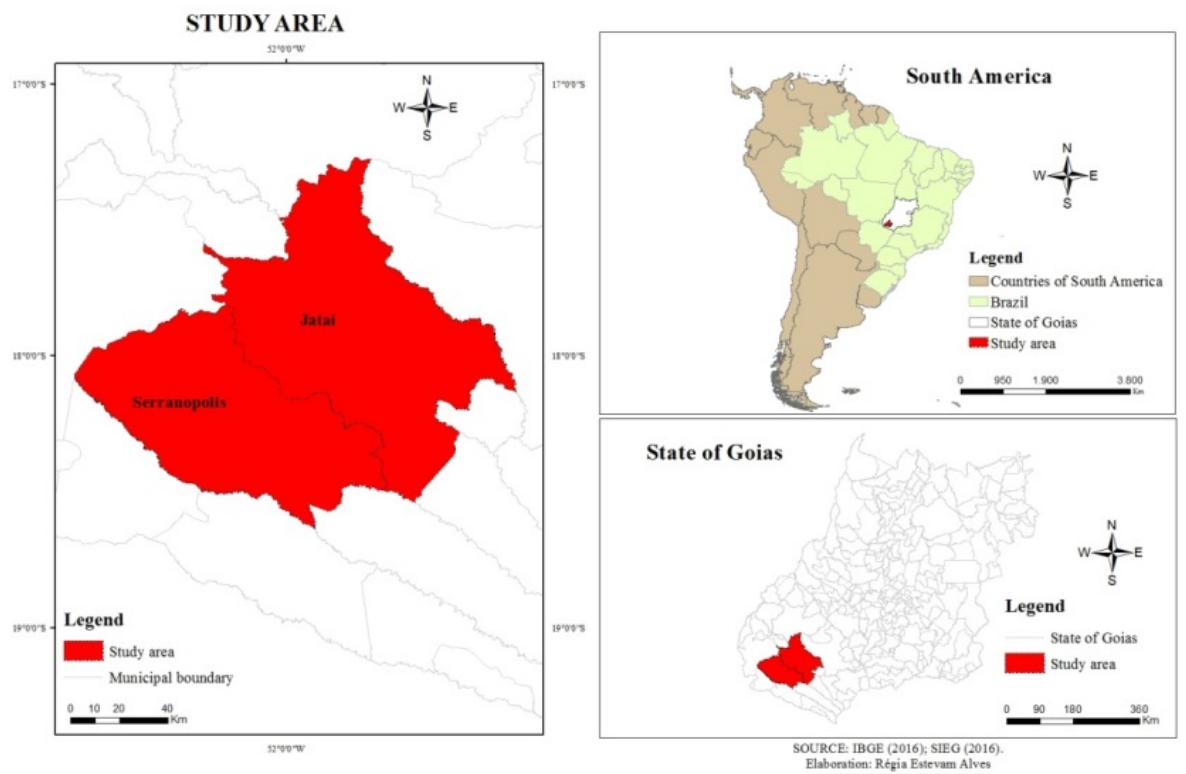

Figure 1. Map of Location of the study area, the municipal districts of Jatai and Serranópolis, in the state of Goiás, Brazil.

According to IBGE data-Brazilian Institute of Geography and Statistics (2016) the municipal district of Jataí possesses area 625 territorial of $7.174,228 \mathrm{~km}^{2}$ and estimated population in 97.077 inhabitants. However, the municipal district of Serranópolis possesses territorial area a little smaller, being $5.526,723 \mathrm{~km}^{2}$ and estimated population in 8.236 inhabitants. Those two municipal districts are part of an agricultural area that, together with other neighboring municipal districts, they represent one of the main participations in the agricultural production of Brazil. 


\section{How the pictures help to understand the agricultural expansion in those municipal districts}

There are a wide geographical themes that can be approached from the photographic registration use. However, in this work it was chosen the agricultural activities as theme for that approach, referring to the years of 1995 and 2014. From the decade of 70 of the Century xx a process of agricultural expansion began in the area of the municipal districts of Jataí and Serranópolis. The decade of 90 , of the Century $x x$ can be considered the peak of that expansion that had as impulse the Brazilian government's incentives and of the agricultural modernization as it is shown in the Figure $2 \mathrm{~A}$ and $\mathrm{B}$; and the prominence of the corn production in the year of 1989 (Figure 2B).
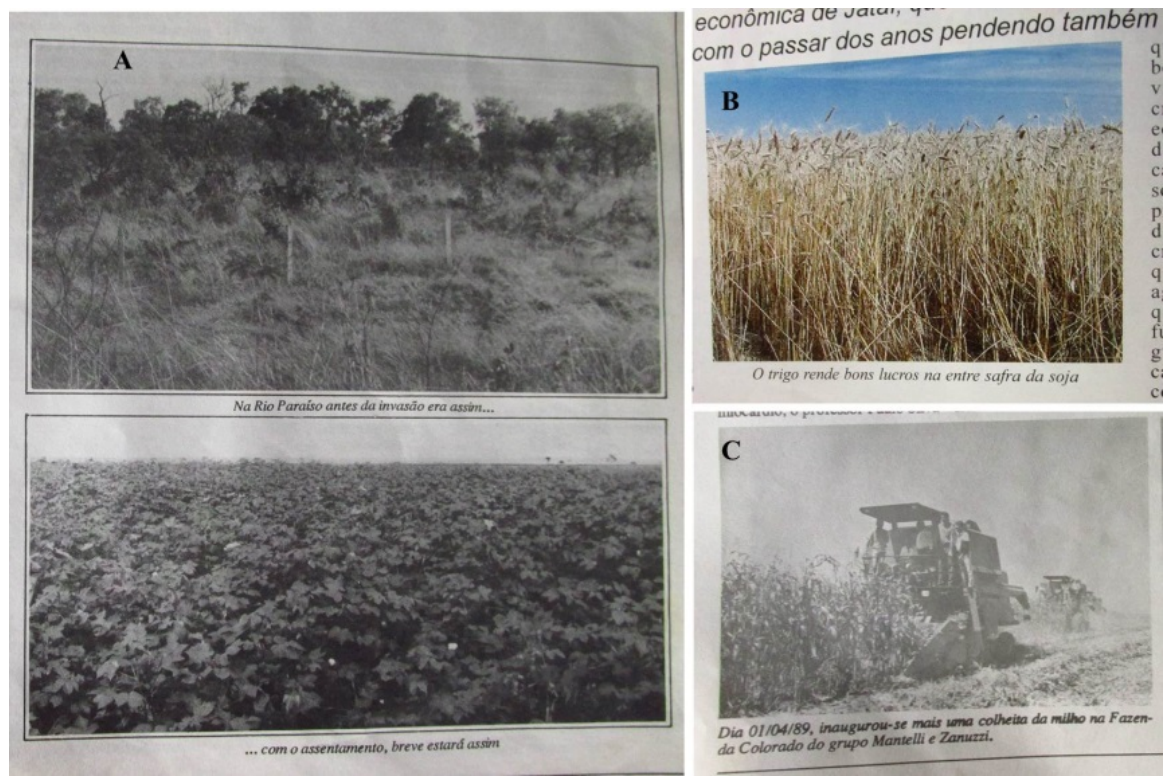

Figure 2. A. The incentive for the agricultural expansion in the beginning of the decade of 90 , of the century $x x$; B. News detaching the planting of the wheat among the crops of soys in the municipal district of Jataí; C. Corn Crop in the municipal district of Jataí in the years of 1989 and 1995. Source: Revista Metas.

Before the expansion and agricultural modernization, it prevailed in the municipal districts of Jataí and Serranópolis the livestock activities and agricultural cultivations of subsistence. However, with the agricultural expansion, the cultivated species, as rice and bean, little by little they had been substituted by monocultures for export. For instance, the soy, the sorgo, the corn, and more recently the sugar-cane, as it displays the Figure 3. 


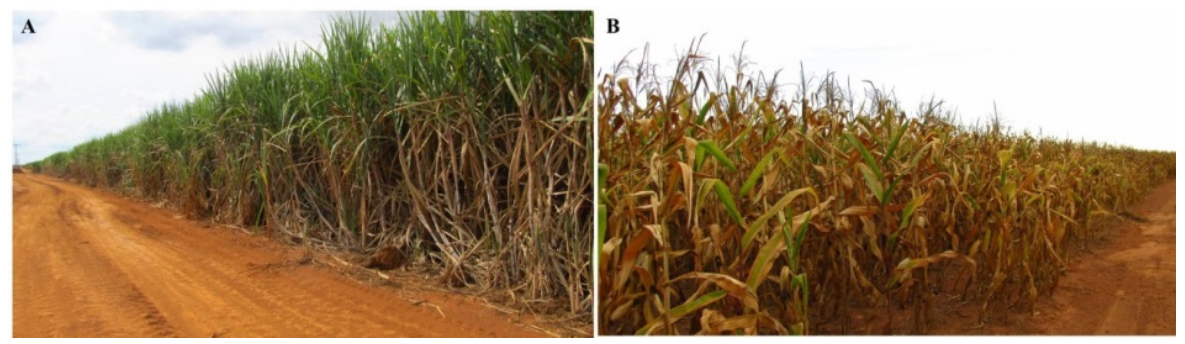

Figure 3. A. Sugar-cane Farming in the municipal district of Jataí; B. Corn Farming in the municipal district of Serranópolis, in the state of Goiás, Brazil. Year of 2016.

From the Figure 4 it's possible to observe the difference of planted area, for hectare, for type of species of agricultural cultivation, among the years from 1995 to 2014 in the municipal district of Jataí. The soy cultivations present larger.

When it refers to the agricutural production for cultivared species, in the municipal district of Jataí the Figure 5 displays a difference between planted area by hectares and production by tons. Being verified that, in production terms among the years of 1995 and 2014, there was high increase of the agricultural cultivations. The sugar-cane started having large representativity in the agricultural production in the year of 2014.

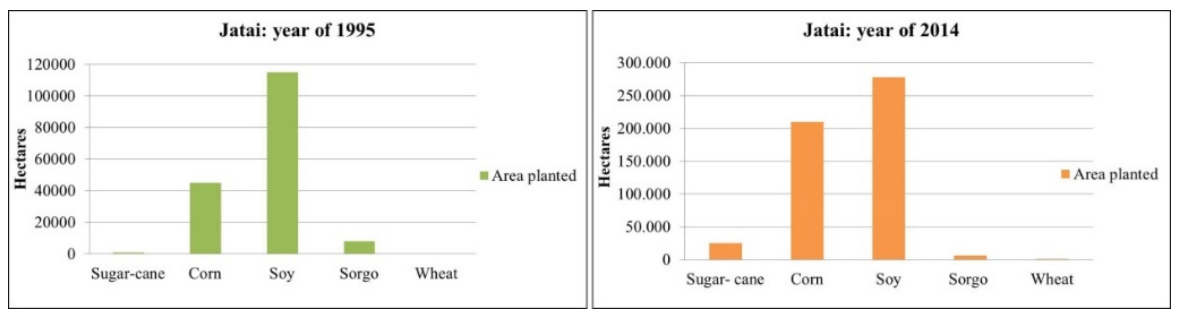

Figure 4. Area planted with temporary farming in the municipal district of Jataí, in the state of Goiás, Brazil in the years of 1995 and 2014.
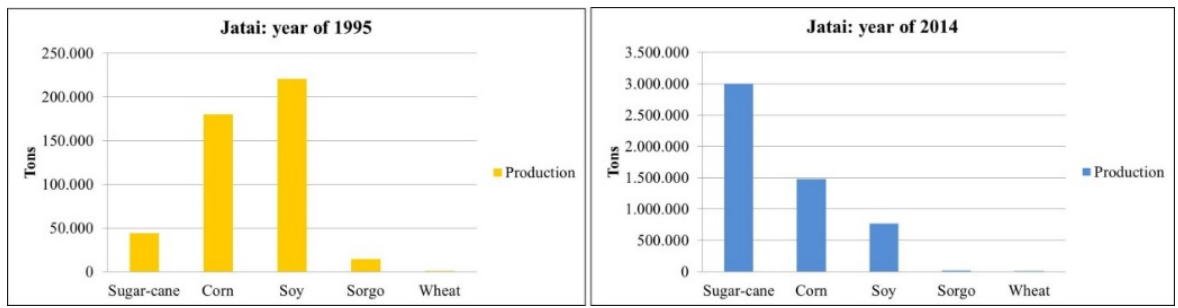

Figure 5. Agricultural production with temporary farming in the municipal district of Jataí, in the state of Goiás, Brazil in the years of 1995 and 2014. 
When comparing planted area by hectares with production for tons, it is noticed a considerable difference, mainly when it is compared to the sugar-cane cultivations and soy. That can be linked to the concentration of the agricultural productivity in small areas and also the largest production capacity. In relation to the municipal district of Serranópolis, as it displays the Figure 6 , the area planted by hectare among the years of 1995 and 2014 it is practically the same.

In relation to the agricultural production in the municipal district of Serranópolis, it is observed in the Figure 7 that, among the years of 1995 and 2014, the sugar-cane production practically triplicated. However, there was not a lot of difference when compared with the municipal district of Jataí, in the Figure 5.

Although, this study had for objective to analyze the old and actual pictures to understand the new agricultural arrangements having as support the data of planted area and production, it is necessary to clear that the agricultural expansion occurred mainly in the municipal district of Jataí, where most of the pastures gave place to the agricultural cultivations. In the municipal district of Serranópolis cattle activities still prevails, although in the last years it has increased distinctly the agricultural activities, prevailing corn cultivations, sugarcane and the eucalyptus.
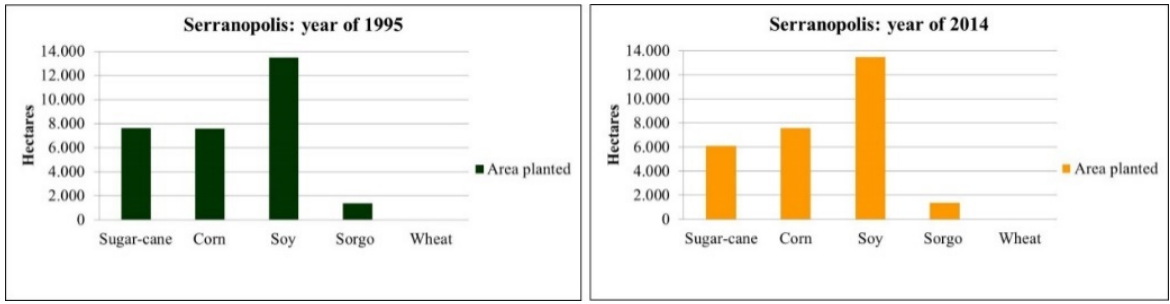

Figure 6. Area planted with temporary farming in the municipal district of Serranópolis, in the state of Goiás, Brazil in the years of 1995 and 2014.

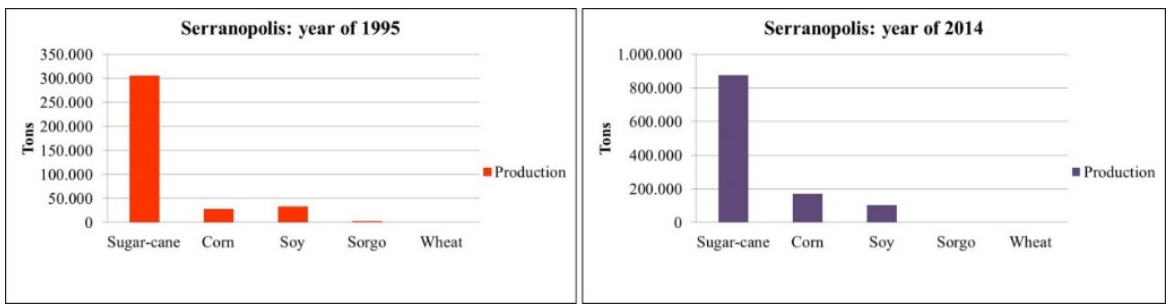

Figure 7. Agricultural production with temporary farming in the municipal district of Serranópolis, in the state of Goiás, Brazil in the years of 1995 and 2014. 


\section{Final considerations}

The use of the old pictures together with the current ones, in this study, made possible to understand the data of agricultural production in the municipal districts of Jataí and Serranópolis, because the numbers are much more representative when accompanied of images, because it shows the decoded reality. Being emphasized, like this, the importance of the use of pictures in geographical studies. Beyond, of the importance of the conservation of the pictures collection whether they are individual or published in news sections of newspapers and magazines, because not always it is easy to find old pictures of a certain one that can help to understand the historical process of a certain fact or phenomenon. Like this, the registration of an image is going besides marking a fact, or phenomenon. It means to register the history, the information and even concept on something.

\section{Bibliography}

Abrantes, V.L.C., "O arquivo fotográfico do Instituto Brasileiro de Geografia e Estatística e o olhar de Tibor Jablonszky sobre o trabalho feminino", in Manguinhos, 20(1): 289306, Rio de Janeiro, 2013.

Bass, J. Trees, "Repeat Photography and Pathways to Landscape Transition in Honduras", Revista Geográfica, 150: 55-74, 2011.

Claval, P., História da Geografia, Edições 70, p. 140, 2006.

Humbert. A., "De l'utilité pour la géographie de l'observation et de la photographie aériennes obliques (note méthodologique à partir d'une expérience récente)", in Mélanges de la casa de Velázquez, 15: 485-488, France, 1979.

Istituto Brasileiro de Geografia e Estatística (IBGE). Censo Demográfico do Brasil. Available at: <https://cidades.ibge.gov.br/>. Accessed on March 15, 2016.

Izidoro, R.; Correia, F., "Fotografia como dispositivo na construção do conhecimento geográfico: a experiência no Mucambo", Revista Intersaberes, 12(26): 298-313, 2017.

Monteiro, C., "História, fotografia e cidade: reflexões teórico-metodológicas sobre o campo de pesquisa", MÉTIS: história e cultura, 5(9): 11-23, 2006.

Revista Metas, Economia, 16: 15, Jataí, 1989.

Revista Metas, Economia, 45: 20, Jataí, 1995.

Rios, S.O.; Costa, J.M.A.; Mendes, V.L.P.S., "Photography as a technique and object of study in qualitative Research", Discursos Fotográficos, 12(20): 98-120, 2016.

Silva, A.F. y Ramírez, A.C., "Geography and photographic images: approximations between places”, Entre-Lugar, 5(9): 52-67, 2014.

Warren, S., "Visual Methods in Organizational Research", in Buchanan, David A. and Bryman, Alan (eds.), The SAGE Handbook of Organizational Research Methods, Londres, Sage Publications Inc., 2009, pp. 566-582. 